ROCZNIK

TEOLOGII

KATOLICKIEJ

Tom X

Rok 2011

Ks. Andrzej Proniewski

Uniwersytet $w$ Białymstoku

\author{
BIBLIOGRAFIA ARTYKUŁÓW \\ W BIULETYNACH I ROCZNIKACH \\ MIĘDZYWYDZIAŁOWEJ KATEDRY \\ TEOLOGII KATOLICKIEJ UNIWERSYTETU \\ W BIAŁYMSTOKU W PIERWSZYM \\ DZIESIĘCIOLECIU SWEGO ISTNIENIA
}

\title{
PUBLICATIONS IN BULLETINS AND JOURNALS IN THE FIRST DECADE OF THE INTERFACULTY CHAIR OF CATHOLIC THEOLOGY OF THE UNIVERSITY OF BIAŁYSTOK
}

Biuletyny: 18 (2000), 19 (2001)

I. Teologia dogmatyczna

A) Zagadnienia ogólne

1. Ozorowski E., Teologia jako nauka, w: „Studia Teologiczne” 18 (2000). „Biuletyn Katedry Teologii Katolickiej Uniwersytetu w Białymstoku” 1/2000, s. 313-316.

2. Rec. Sieńkowski M.: Szczepaniec S., Odpust - dar pełnej wolności, Wydawnictwo UNUM, Kraków 2000, w: „Studia Teologiczne” 18 (2000). „Biuletyn Katedry Teologii Katolickiej Uniwersytetu w Białymstoku” 1/2000, s. 481-483.

3. Rec. Kulik B.: Nadolski B., Pochwała Święta, Wydawnictwo Pallotinum, Poznań 1997, w: „Studia Teologiczne” 18 (2000). „Biuletyn Katedry Teologii Katolickiej Uniwersytetu w Białymstoku" 1/2000, s. 484. 


\section{B) Chrystologia}

1. Rec. Skierkowski M.: Gnilka J., Jezus z Nazaretu. Orędzie i dzieje (w przekładzie J. Zychowicza), Kraków 1997, w: „Studia Teologiczne” 18 (2000). „Biuletyn Katedry Teologii Katolickiej Uniwersytetu w Białymstoku” 1/2000, s. 462-470.

\section{C) Sakramenty}

\section{Eucharystia}

1. Ozorowski E., Świętość Eucharystii, w: „Studia Teologiczne” 18 (2000). „Biuletyn Katedry Teologii Katolickiej Uniwersytetu w Białymstoku" 1/2000, s. 337-348.

\section{Teologia moralna}

1. Rec. Bartnicki A.: Bołoz W., Życie w ludzkich rękach. Podstawowe zagadnienia bioetyczne, Wydawnictwo Akademii Teologii Katolickiej, Warszawa 1997, w: „Studia Teologiczne” 18 (2000). „Biuletyn Katedry Teologii Katolickiej Uniwersytetu w Białymstoku" 1/2000, s. 478-480.

2. Rec. Dołęga J. M.: Filipowicz A., Bioetyka Van Rensselaera, Pottera i jej ocena $w$ świetle moralnego nauczania Jana Pawła II, Warszawa 1999, w: „Studia Teologiczne” 18 (2000). „Biuletyn Katedry Teologii Katolickiej Uniwersytetu w Białymstoku" 1/2000, s. 511-512.

3. Michniewicz W., Postępy biologii i medycyny - nadzieje i niepokoje, w: „Studia Teologiczne” 19 (2001). „Biuletyn Katedry Teologii Katolickiej Uniwersytetu w Białymstoku" 2/2001, s. 45-52.

4. Zabielski J., Życie jako wartość, w: „Studia Teologiczne” 19 (2001). „Biuletyn Katedry Teologii Katolickiej Uniwersytetu w Białymstoku" 2/2001, s. 53-74.

5. Zabielski J., Archeus - studia z bioetyki i antropologii filozoficznej, w: „Studia Teologiczne” 19 (2001). „Biuletyn Katedry Teologii Katolickiej Uniwersytetu w Białymstoku" 2/2001, s. 79-82.

\section{Liturgika}

1. Hołodok S., Sprawowanie Eucharystii w Archidiecezji Białostockiej dziś (blaski i cienie), w: „Studia Teologiczne” 18 (2000). „Biuletyn Katedry Teologii Katolickiej Uniwersytetu w Białymstoku” 1/2000, s. 349-364.

2. Rec. Maczan M.: Durak A., Uroczystość Najświętszego Ciała i Krwi Chrystusa. Analiza hermeneutyczna tekstów celebracji, Kraków 1999, w: „Studia Teologiczne” 18 (2000). „Biuletyn Katedry Teologii Katolickiej Uniwersytetu w Białymstoku" 1/2000, s. 485. 


\section{Teologia pastoralna}

\section{A) Ogólne zagadnienia pastoralno-katechetyczne}

1. Rec. Stankiewicz M.: Hajduk A., Katecheza i liturgia, Wydawnictwo WAM, Kraków 1999, w: „Studia Teologiczne” 18 (2000). „Biuletyn Katedry Teologii Katolickiej Uniwersytetu w Białymstoku” 1/2000, s. 486.

\section{B) Duszpasterstwo rodzin}

1. Rec. Pachucki K.: Grzybowski J., Nadzieja odzyskana. Drogowskazy dla matżeństw niesakramentalnych, Kraków 1998, w: „Studia Teologiczne” 18 (2000). „Biuletyn Katedry Teologii Katolickiej Uniwersytetu w Białymstoku” 1/2000, s. 491-492.

\section{Teologia ascetyczna}

\section{A) zagadnienia ogólne}

1. Rec. Ołów M.: Heron B., Ujrzałem spadającego szatana. Metody walki duchowej, Wydawnictwo Księży Marianów, Warszawa 1998, w: „Studia Teologiczne” 18 (2000). „Biuletyn Katedry Teologii Katolickiej Uniwersytetu w Białymstoku" 1/2000, s. 487.

\section{B) Wzory życia}

1. Ciereszko H., Heroiczny wymiar życia i cnót Księdza Michała Sopoćki, w: „Studia Teologiczne” 18 (2000). „Biuletyn Katedry Teologii Katolickiej Uniwersytetu w Białymstoku" 1/2000, s. 365-388.

\section{Historia Kościoła}

\section{A) Kościoły i parafie}

1. Jemielity W., Zmiana granic parafii $w$ diecezji augustowskiej czyli sejneńskiej, w: „Studia Teologiczne” 18 (2000). „Biuletyn Katedry Teologii Katolickiej Uniwersytetu w Białymstoku" 1/2000, s. 412-430.

2. Rec. Dziekoński S.: Czartoszewski J. W., Dołęga J. M., Z dziejów chrześcijaństwa w Augustowie, w: „Studia Teologiczne” 18 (2000). „Biuletyn Katedry Teologii Katolickiej Uniwersytetu w Białymstoku” 1/2000, s. 507-508.

3. Rec. Czartoszewski W.: Sokołowski J., Parafia Osowiec w środowisku społecznym i przyrodniczym, „Episteme” 5 (2000), „Acta Universitatis Masuriensis”, Olecko 2000, w: „Studia Teologiczne” 18 (2000). „Biuletyn Katedry Teologii Katolickiej Uniwersytetu w Białymstoku” 1/2000, s. 509-511. 


\section{B) Inne zagadnienia historyczne}

1. Rec. Dziekanowski C.: Red. Wójtowicz K., Życie konsekrowane w trzecim wieku, Wydawnictwo Zmartwychwstańców Alleluja, Kraków 2000, w: „Studia Teologiczne” 18 (2000). „Biuletyn Katedry Teologii Katolickiej Uniwersytetu w Białymstoku" 1/2000, s. 493.

2. Rec. Karski K.: Góralski W., Konkordat polski 1993. Od podpisania do ratyfikacji, Wydawnictwo Akademii Teologii Katolickiej, Warszawa 1998, w: „Studia Teologiczne” 18 (2000). „Biuletyn Katedry Teologii Katolickiej Uniwersytetu w Białymstoku" 1/2000, s. 504-505.

\section{Prawo kanoniczne}

1. Kakareko A., Prawo - szansa czy zagrożenie? Kościelny punkt widzenia, w: „Studia Teologiczne” 18 (2000). „Biuletyn Katedry Teologii Katolickiej Uniwersytetu w Białymstoku" 1/2000,s. 323-336.

2. Warchałowski K., Wymogi prawne prowizji kanonicznej w kodeksie prawa kanonicznego Benedykta XV i Jana Pawła II, w: „Studia Teologiczne” 18 (2000). „Biuletyn Katedry Teologii Katolickiej Uniwersytetu w Białymstoku” 1/2000, s. 431-440.

3. Rec. Warchałowski K.: Zieliński T., Czas prawa i bezprawia - myśli niepokorne kustosza praw, Dom Wydawniczy ABC, Warszawa 1999, w: „Studia Teologiczne” 18 (2000). „Biuletyn Katedry Teologii Katolickiej Uniwersytetu w Białymstoku" 1/2000, s. 500-503.

\section{Nauki biblijne}

1. Michniewicz W., Znaczenie terminów biblijnych kuttōnet $i$ ketōnet passîm, w: „Studia Teologiczne” 18 (2000). „Biuletyn Katedry Teologii Katolickiej Uniwersytetu w Białymstoku" 1/2000, s. 401-411.

2. Rec. Przyborowski B.: Mazur Z., Introdukcja biblijna. Wstęp do Biblii, Giżycko - Ełk 2000, w: „Studia Teologiczne” 18 (2000). „Biuletyn Katedry Teologii Katolickiej Uniwersytetu w Białymstoku” 1/2000, s. 460-461.

3. Rec. Czartoszewski J. W.: Czaczkowska I., Pomiędzy potopem a tęczą. Ekumeniczne studium integralności stworzenia, RW KUL, Lublin 1998, w: „Studia Teologiczne” 18 (2000). „Biuletyn Katedry Teologii Katolickiej Uniwersytetu w Białymstoku" 1/2000, s. 476-477.

\section{Religioznawstwo}

1. Rec. Rutkowski P.: Red. Ledwoń I. S., Pek K., Chrześcijaństwo a religie. Dokument Międzynarodowej Komisji Teologicznej, Tekst - Komentarze - Studia, 
Lublin - Warszawa 1999, w: „Studia Teologiczne” 18 (2000). „Biuletyn Katedry Teologii Katolickiej Uniwersytetu w Białymstoku" 1/2000, s. 471-472.

2. Rec. Szyłak A., Maurier H.: Antropologia misyjna. Religie i cywilizacje w zderzeniu z uniwersalizmem. Przyczynek do dziejów wspótczesnych, Wydawnictwo Księży Werbistów Verbinum, Warszawa 1998, w: „Studia Teologiczne” 18 (2000). „Biuletyn Katedry Teologii Katolickiej Uniwersytetu w Białymstoku” 1/2000, s. 488-490.

3. Rec. Rendziński S.: Red. Nowak W., Ekumeniczny leksykon Kościołów i Wspólnot religijnych województwa warmińsko-mazurskiego, Wydział Duszpasterski Kurii Metropolitalnej Archidiecezji Warmińskiej, Olsztyn 1999, w: „Studia Teologiczne” 18 (2000). „Biuletyn Katedry Teologii Katolickiej Uniwersytetu w Białymstoku" 1/2000, s. 506.

\section{Patrologia}

1. Rec. Kopiczko T.: Drączkowski F., Patrologia, Bernardinum, Pelplin-Lublin 1998, w: „Studia Teologiczne” 18 (2000). „Biuletyn Katedry Teologii Katolickiej Uniwersytetu w Białymstoku” 1/2000, s. 498-499.

\section{Filozofia}

1. Gładczuk Cz., Przestrzeń ludzkiej wiedzy. Niektóre implikacje encykliki Wiara i rozum, w: „Studia Teologiczne” 18 (2000). „Biuletyn Katedry Teologii Katolickiej Uniwersytetu w Białymstoku" 1/2000, s. 441-451.

2. Rec. Składanowski M.: Wojtyła K., Rozważania o istocie człowieka, Wydawnictwa WAM, w: „Studia Teologiczne” 18 (2000). „Biuletyn Katedry Teologii Katolickiej Uniwersytetu w Białymstoku" 1/2000, s. 473-475.

3. Rec. Gładczuk Cz.: Kunzman P., Burkard F. P., Wiedmann F., Atlas filozofii, opracowanie graficzne Axel Weiss, przekład Markiewicz B. A., Pruszyński i S-ka, Warszawa 1999, w: „Studia Teologiczne” 18 (2000). „Biuletyn Katedry Teologii Katolickiej Uniwersytetu w Białymstoku” 1/2000, s. 494.

4. Rec. Radziłowicz M., Zubrzycki K.: Kłoskowski K., Filozofia ewolucji i filozofia stwarzania, t. 1: Między ewolucja a stwarzaniem; t. 2: Pogodzone bliźniaki Rzecz o ewolucji i stwarzaniu, Wydawnictwo Akademii Teologii Katolickiej, Warszawa 1999, w: „Studia Teologiczne” 18 (2000). „Biuletyn Katedry Teologii Katolickiej Uniwersytetu w Białymstoku" 1/2000, s. 495-497.

5. Kopania J., Ratio Querens Fidem, w: „Studia Teologiczne” 19 (2001). „Biuletyn Katedry Teologii Katolickiej Uniwersytetu w Białymstoku" 2/2001, s. 11-22.

6. Gładczuk Cz., Nauka i wiara - przeciwstawne czy też zborne?, w: „Studia Teologiczne” 19 (2001). „Biuletyn Katedry Teologii Katolickiej Uniwersytetu w Białymstoku" 2/2001, s. 23-34. 
7. Skreczko A., Czy posiadamy zmysł religijny?, w: „Studia Teologiczne” 19 (2001). „Biuletyn Katedry Teologii Katolickiej Uniwersytetu w Białymstoku” 2/2001, s. 35-38.

8. Kopania J., Człowiek poszukujacy sensu istnienia, w: „Studia Teologiczne” 19 (2001). „Biuletyn Katedry Teologii Katolickiej Uniwersytetu w Białymstoku" 2/2001, s. 39-40.

9. Ciereszko H., Homo religiosus - człowiek istota religijna?, w: „Studia Teologiczne” 19 (2001). „Biuletyn Katedry Teologii Katolickiej Uniwersytetu w Białymstoku" 2/2001, s. 41-44.

\section{Dział ogólny}

\section{A) Od redakcji, słowa wstępne}

1. Zabielski J., Od wydawcy - słowo Redaktora Biuletynu, w: „Studia Teologiczne” 18 (2000). „Biuletyn Katedry Teologii Katolickiej Uniwersytetu w Białymstoku" 1/2000, s. 309-310.

2. Zabielski J., Od redakcji, 19 (2001), s. 3-4.

B) Sprawozdania z konferencji, sympozjów i działalności naukowej

1. Michniewicz W., Sprawozdanie z sesji popularnonaukowej na temat Eucharystii Bialystok AWSD, 8 I 2000 r., w: „Studia Teologiczne” 18 (2000). „Biuletyn Katedry Teologii Katolickiej Uniwersytetu w Białymstoku" 1/2000, s. 317-322.

2. Ozorowski M., Protokół ze spotkań Księży Profesorów WSD z Białegostoku, Drohiczyna, Łomży i Siedlec w roku akademickim 1999/2000, w: „Studia Teologiczne” 18 (2000). „Biuletyn Katedry Teologii Katolickiej Uniwersytetu w Białymstoku" 1/2000, s. 452-456.

3. Dziekoński S., Sprawozdanie z sympozjum katechetycznego $w$ Łomży $w$ dniu 7 stycznia 2000, w: „Studia Teologiczne” 18 (2000). „Biuletyn Katedry Teologii Katolickiej Uniwersytetu w Białymstoku” 1/2000, s. 457-459.

4. Kasabuła T., Katedra Teologii Katolickiej Uniwersytetu w Białymstoku - sprawozdanie z działalności za okres 8 X 1999 - 31 XII 2000, w: „Studia Teologiczne” 19 (2001). „Biuletyn Katedry Teologii Katolickiej Uniwersytetu w Białymstoku" 2/2001, s. 5-10.

5. Kasabuła T., Jubileuszowe spotkanie pracowników nauki, w: „Studia Teologiczne” 19 (2001). „Biuletyn Katedry Teologii Katolickiej Uniwersytetu w Białymstoku" 2/2001, s. 75-78.

\section{C) Inne}

1. Uchwała Senatu Uniwersytetu w Białymstoku z dnia 14 października 1998 roku w sprawie utworzenia Katedry Teologii Katolickiej, w: „Studia 
Teologiczne” 18 (2000). „Biuletyn Katedry Teologii Katolickiej Uniwersytetu w Białymstoku" 1/2000, s. 311.

2. Umowa dotycząca funkcjonowania Katedry Teologii Katolickiej w Uniwersytecie w Białymstoku, w: „Studia Teologiczne” 18 (2000). „Biuletyn Katedry Teologii Katolickiej Uniwersytetu w Białymstoku" 1/2000, s. 311.

3. Nitkiewicz K., Sens i stan starań o beatyfikację ks. Michała Sopoćki, w: „Studia Teologiczne” 18 (2000). „Biuletyn Katedry Teologii Katolickiej Uniwersytetu w Białymstoku" 1/2000, s. 389-399.

\section{Roczniki Teologii Katolickiej I-X (2002-2012)}

\section{Teologia dogmatyczna}

\section{A) Zagadnienia ogólne}

1. Rec. Zabielski J.: Ozorowski E., Dialogi o Bożym Miłosierdziu, Białystok 2003, 2 (2003), s. 146-150.

2. Rec. Skreczko A.: O’Collins G., Farrugia E., Leksykon pojęć kościelnych i teologicznych, przełożyli ks. Ożóg J. SJ, Żak B., Wydawnictwo WAM, Kraków 2002, 2 (2003), s. 162-164.

3. Ozorowski E., Teologia peregrynacji obrazu Jezusa Miłosiernego, 7 (2008), s. 64-70.

4. Rec. Wieczyński F.: Lewandowski J., W nadziei jesteśmy odkupieni. Komentarz do encykliki Benedykta XVI „Spe salvi”, Wydawnictwo Archidiecezji Warszawskiej, Warszawa 2008, s. 209, 7 (2008), s. 327-328.

5. Ozorowski E., Fides qua - fides quae, 8 (2009), s. 33-41.

6. Depo W. T., Bądźmy świadkami miłości - aspekt dogmatyczny, 9 (2010), s. 9-17.

7. Biela B., Wspótczesne zagrożenia wiary od zewnątrz, 9 (2010), s. 39-63.

8. Proniewski A., Doświadczenie wiary w życiu młodego człowieka w nauczaniu Benedykta XVI, 9 (2010), s. 94-106.

9. Pałubska Z., Kult Opatrzności Bożej w Kościele katolickim w Polsce, 9 (2010), s. 180-207.

10. Dziewulski G., Epifanijny charakter tożsamości człowieka i jego znaczenie dla obecności Kościoła w społeczeństwie (po)nowoczesnym, 10 (2011), s. 48-66.

11. Proniewski A., Problematyka wiary w nauczaniu Benedykta XVI, 10 (2011), s. 113-130.

12. Rec. Dziegielewska A.: Ozorowski E., Słownik podstawowych pojęć teologicznych, Wydawnictwo UKSW, Warszawa 2007, 10 (2011), s. 250-253. 


\section{B) Chrystologia}

1. Rec. Pałubska Z.: Sopoćko M., Jezus - Król Miłosierdzia. Artykuły z lat 19361975, zebrał ks. A. Skreczko, Wydawnictwo Księży Marianów, Warszawa 2005, 4 (2005), s. 258-261.

2. Dziuba A. F., Jezus Chrystus - eschatologiczny dar pełni czasu, 5 (2006), s. 23-46.

\section{C) Eklezjologia}

1. Salij J., Jak dzisiaj mówić o kościele?, 6 (2007), s. 32-44.

2. Dzięgielewska A., Przynależność do Kościoła a problem zbawienia według „Lumen Gentium” i „Dominus Iesus”, 8 (2009), s. 149-166.

3. Hofmann J., Znaczenie Kościoła rzymskiego i jego biskupa dla Kościoła powszechnego od "konstantyńskiego przełomu” do Soboru Chalcendońskiego (451), 8 (2009), s. 175-192.

4. Rec. Olszewski M.: Böttigheimer Ch. Hofmann J., Autorität und Synodalität. Eine interdisziplinäre und interkonfessionelle Umschau nach ökumenischen Chancen Und ekklesiologischen Desideraten, Frankfurt AM Main, Verlag Otto Lembeck 2008, 8 (2009), s. 212-216.

5. Rec. Pałubska Z.: Dziura R., Dialog z religijno-społeczna tradycją ludów Zambii w świetle posoborowej nauki Kościoła, Wydawnictwo KUL, Lublin 2009, 9 (2010), s. 265-267.

6. Pietrusiak P., Kościót jako „fraternitas” według Cypriana z Kartaginy, 10 (2011), s. 67-87.

\section{D) Sakramenty}

\section{Eucharystia}

1. Ozorowski E., Ofiara jako „primum principium” Eucharystii, 5 (2006), s. 9-21.

2. Proniewski A., Ostatnia Wieczerza Jezusa w kontekście żydowskiej uczty paschalnej, 6 (2007), s. 57-67.

3. Proniewski A., Eucharystia jako ofiara miłości i miłosierdzia według Błogosławionego ks. Michała Sopoćki, 7 (2008), s. 47-63.

\section{Kapłaństwo}

1. Skreczko A., Kapłan jako szafarz Miłosierdzia Bożego według bł. ks. Michała Sopoćki, 7 (2008), s. 110-119.

2. Puchalska-Dąbrowska B. M., Obraz kapłana-męczennika doby potrydenckiej $w$ „Żywotach świętych” Piotra Skargi, 9 (2010), s. 107-114.

\section{Małżeństwo}

1. Ozorowski E., Małżeństwo jako związek mężczyzny i kobiety, 2 (2003), s. 7-25.

2. Rec. Stala J.: Szymczak J., Sakrament małżeństwa droga wzrostu Kościoła. Urzeczywistnianie się Kościoła w sakramencie małżeństwa w nauczaniu Jana 
Pawła II latach 1978-1987, Wydawnictwo: „Fundacja Pomocy Rodzinie”, Łomianki 2001, 6 (2007), s. 228-230.

3. Rec. Stala J.: Nosowski Z., Parami do nieba. Małżeńska droga do świętości, Biblioteka „Więzi”, Warszawa 2004, 8 (2009), s. 222-225.

\section{E) Kreatologia}

1. Proniewski A., Implikacje protologiczne Tomasza z Akwinu, 4 (2005), s. 39-46.

\section{Teologia moralna}

1. Zabielski J., Sytuacja rodziny w Polsce dziś, 2 (2003), s. 27-40.

2. Morciniec P., Etyczne granice transplantacji, 2 (2003), s. 75-88.

3. Rec. Zabielski J.: Mieth D., Was wollen wir können? Ethik im Zeitalter der Bioethik, Freiburg 2003/2004, 3 (2004), s. 169-172.

4. Gacka B., Godność osoby i godność narodu, 4 (2005), s. 19-28.

5. Zabielski J., Normatywny charakter nowego porządku światowego, 4 (2005), s. 29-37.

6. Rec. Dziuba A. F.: Pontificio Consiglio per la Famiglia, Famiglia e questioni etiche, Edizioni Dehoniane, Bologna 2004, 5 (2006), s. 286-290.

7. Rec. Skreczko A.: Zabielski J., Wydobywanie dobra. Teologia chrześcijańskiego miłosierdzia, Wydawnictwo Uniwersytetu w Białymstoku, Białystok 2006, 5 (2006), s. 309-313.

8. Ozorowski E., Dziecko w aspekcie celu, 6 (2007), s. 11-17.

9. Zabielski J., Dydaktyka moralności - moralność dydaktyki, 6 (2007), s. 68-75.

10. Kobylińska Z., Wychowanie moralne w kulturze pokus, 6 (2007), s. 76-83.

11. Rec. Zabielski J.: Piwowarczyk J., Bieda jako wyzwanie duszpasterskie w świetle nauczania Jana Pawła II, Kraków 2007, 6 (2007), s. 213-219.

12. Góralczyk P., Odkryć w sobie niepowtarzalna godność, 8 (2009), s. 59-70.

13. Zabielski J., Chrześcijańskie miłosierdzie jako personalistyczna zasada życia społecznego, 8 (2009), s. 71-84.

14. Zabielski J., Aretologiczne „umocowanie” życia społeczno-moralnego, 9 (2010), s. 64-78.

15. Rec. Zabielski J.: Zwoliński A., Grzechy cudze, wyd. WAM, Kraków 2009, 9 (2010), s. 246-250.

16. Rec. Stala J.: Red. Gryz K., Człowiek droga Kościoła. Moralne aspekty nauczania Jana Pawła II, Wydawnictwo Świętego Stanisława BM, Kraków 2004, 9 (2010), s. 251-254.

17. Rec. Skreczko A.: Zabielski J., Teologiczno-etyczne podstawy ładu społecznego, Wydawnictwo Uniwersytetu w Białymstoku, Białystok 2010, 9 (2010), s. 276-278. 


\section{Liturgika}

\section{A) Historia liturgii}

1. Baranowski T., Kontemplacja, interpretacja, stylizacja. Refleksje o przemianach gatunku mszy w dziejach muzyki europejskiej, 2004, t. 3, s. 95-104.

\section{B) Teksty liturgiczne}

1. Powichrowski T., Elementy pojednania w liturgii eucharystycznej i mistagogia modlitw eucharystycznych o tajemnicy pojednania, 5 (2006), s. 71-117.

2. Powichrowski T., Struktura formalna modlitwy eucharystycznej, 6 (2007), s. $129-148$.

\section{Teologia pastoralna}

\section{A) Ogólne zagadnienia pastoralno-katechetyczne}

1. Rec. Skreczko A.: Catholic Education. European and Maltese Perspective. Church Schools' response to future challenges, Floriana 2004, 3 (2004), s. 184-186.

2. Rec. Stala J.: Połeć B., Metodyka katechetyczna ks. Waldemara Gadowskiego, Wydawnictwo: Poligrafia Redemptorystów w Tuchowie, Tarnów 2002, 6 (2007), s. 235-240.

3. Rec. Stala J.: Stala J., Osewska E., Fundamentalne podstawy i obszary katechezy rodzinnej, Tarnów 2000, 6 (2007), s. 231-234.

4. Grzegorczyk J., Aktualna sytuacja pastoralna w Polsce. Wybrane aspekty, 7 (2008), s. 222-233.

5. Biela B., Katecheza $w$ świetle zasady formalnej teologii pastoralnej, 7 (2008), s. 234-247.

6. Rec. Skreczko A.: Red. Kamiński R., Przygoda W., Fijałkowski M., Leksykon teologii pastoralnej, Towarzystwo Naukowe KUL, Lublin 2006, 7 (2008), s. 329-331.

7. Rec. Stala J.: Skreczko A., Grużewski B., Nauczanie religii i postawy katechetów Wileńszczyzny, Warszawa - Białystok - Wilno 2008, 7 (2008), s. 332-334.

8. Rec. Dziuba A. F.: Robek E., Kościołowi w Polsce powiedz... Refleksja teologiczno pastoralna, Warszawa 2009, 8 (2009), s. 204-206.

9. Stala J., Przyczynek do ukazania tradycji szkolnictwa specjalnego w Polsce, 9 (2010), 170-179.

10. Stala J., Umiejętność działania nauczyciela religii i katechety. W kierunku formacji kształtowania umiejętności pedagogiczno-katechetycznych, 10 (2011), s. 161-170. 
11. Dzięgielewska A., Wychowanie patriotyczne młodzieży przygotowującej się do przyjęcia sakramentu bierzmowania jako element duszpasterstwa młodzieży, 10 (2011), s. 201-211.

12. Kalisz Ł., Wychowanie bez przemocy w systemie prewencyjnym ks. Jana Bosko, 10 (2011), s. 212-220.

\section{B) Duszpasterstwo powołań}

1. Polak W., Duszpasterstwo powołań, 6 (2007), s. 18-31.

2. Kamiński R., Priorytetowe kierunki pracy duszpasterskiej Kościoła w Polsce, 6 (2007), s. 45-56.

3. Lechowicz W., Duszpasterstwo powołaniowe - powołaniem dzisiejszego duszpasterstwa, 10 (2011), s. 41-47.

\section{C) Laikat}

1. Zabielski J., Inspirująca rola katolików świeckich w budowaniu odpowiedzialnych struktur życia społecznego, 5 (2006), s. 131-143.

2. Przygoda W., Diakonia jako wyzwanie dla uczniów Chrystusa dzisiaj, 7 (2008), s. 153-164.

\section{D) Duszpasterstwo rodzin}

1. Skreczko A., Troska Prymasa Tysiąclecia o polska rodzinę, 1 (2002), s. 35-52.

2. Skreczko A., Troska Kościoła katolickiego w Polsce o rodzinę po drugiej wojnie światowej, 2 (2003), s. 41-73.

3. Rec. Zabielski J.: Skreczko A., Troska Kościoła katolickiego w Polsce o matżeństwo i rodzinę $w$ okresie Wielkiej Nowenny Tysiaclecia (1957-1966), Studium teologiczno-pastoralne, Białystok 2002, 2 (2003), s. 151-154.

4. Skreczko A., Rola Kościoła w kształtowaniu kultury pedagogicznej rodziców, 3 (2004), s. 35-49.

5. Rec. Zabielski J.: Skreczko A., Rodzina Bogiem silna, Białystok 2004, 3 (2004), s. $173-176$.

6. Skreczko A., Wychowanie chrześcijańskie w ujęciu księdza Michała Sopoćki, 4 (2005), s. 59-98.

7. Rec. Skreczko A.: Cordes P. J., Zagubione ojcostwo, Pelplin 2005, 4 (2005), s. 255-257.

8. Skreczko A., Rodzicielstwo jako dar i zadanie na podstawie prymasa Stefana Wyszyńskiego podczas Wielkiej Nowenny Tysiąclecia, 5 (2006), s. 145-183.

9. Olszewski M., Rodzina jako podmiot duszpasterstwa $w$ świetle programów duszpasterskich Episkopatu Polski, 5 (2006), s. 185-198.

10. Rec. Stala J.: Krzysteczko H., Pomoc w dojrzewaniu do miłości, małżeństwa i rodziny. Studium teologiczno-pastoralne, „Powiernik rodzin”, Katowice 2000, 5 (2006), s. 317-320. 
11. Rec. Kobylińska Z.: Górniewicz J., Teoria wychowania (wybrane problemy), Olsztyńska Szkoła im. Józefa Rusieckiego, Olsztyn 2007, 6 (2007), s. 225-227.

12. Skreczko A., Zadania rodziny jako Kościoła domowego, 8 (2009), s. 112-121.

13. Stala J., Wybrane wymiary wychowania ludzkiego $w$ rodzinie, 8 (2009), s. $122-133$.

14. Rec. Stala J.: Mierzwiński B., Dybowski E., Oblicze współczesnej rodziny polskiej, Wydawnictwo WAM, Kraków 2003, 8 (2009), s. 226-229.

15. Rec. Pałubska Z.: Druszcz J., Świętość matki w hagiografii, nauczaniu i praktyce Kościoła katolickiego, Olsztyn 2007, 8 (2009), s. 230-233.

16. Ozorowski E., Teologia ojcostwa, 9 (2010), s. 18-24.

17. Skreczko A., Ojcostwo jako zadanie, 9 (2010), s. 25-38.

18. Arbaszewski P., Rodzinne wychowanie do życia wiara w przygotowaniu potomstwa do sakramentu małżństwa, 9 (2010), s. 115-137.

19. Kułaczkowski J., Wierność jako istotna cecha przymierza małżeńskiego a duszpasterstwo rodzin, 9 (2010), s. 138-153.

20. Rec. Stala J.: Red. Offmański A., Małżeństwo i rodzina w panoramie współczesnych systemów, Wydział Teologiczny Uniwersytetu Szczecińskiego, Szczecin 2006, 9 (2010), s. 255-257.

21. Rec. Wójcik J.: Krasnodębski M., Człowiek i paideia. Realistyczne podstawy filozofii wychowania, Wydawnictwo Wyższej Szkoły Przymierza Rodzin w Warszawie, Warszawa 2009, 9 (2010), s. 258-264.

22. Rec. Puchalska-Dąbrowska B.: Skreczko A., Rola Kościoła katolickiego w ksztattowaniu kultury pedagogicznej rodziców w Polsce, Wydawnictwo Trans Humana, Białystok 2011, 10 (2011), s. 258-259.

23. Rec. Skreczko A.: Red. Stala J., Osewska E., W poszukiwaniu katechezy rodziców. Studium teoretyczno-empiryczne. Problemy i wyzwania, Biblos, Tarnów 2007, 10 (2011), s. 263-265.

\section{E) Ewangelizacja}

1. Zabielski J., Ewangelizacja w dobie religijnego zobojętnienia, 3 (2004), s. 19-34.

2. Grzegorczyk J., Potrzeba nowej ewangelizacji, 4 (2005), s. 211-222.

3. Mierzwiński B., Parafia miejscem głoszenia Ewangelii nadziei, 5 (2006), s. $47-60$.

4. Proniewski A., Kościół a świat. Recepcja i aktualizacja myśli Soboru Watykańskiego II, 5 (2006), s. 119-130.

5. Rec. Dziuba A. F.: Lopez Trujillo A., Familia, vida y evangelizatión, Editorial Verbo Divino, Estella (Navarra) 2000, 5 (2006), s. 291-293.

6. Skreczko A., Ewangelizacja w rodzinie i przez rodzinę, 6 (2007), s. 118-128.

\section{F) Inne zagadnienia pastoralne i duszpasterskie}

1. Lewandowski J., Wskazania Prymasa Tysiąclecia dla narodu polskiego, 1 (2002), s. 21-34. 
2. Wojtecki D., Globalizacja w świetle Katolickiej Nauki Społecznej, 1 (2002), s. 103-111.

3. Przybylski A., Świadczenie miłości i miłosierdzia w parafii, 5 (2006), s. 61-70.

4. Rec. Stala J.: Ślusarz A., Psychopedagogika rodziny księdza Piotra Poręby, Wydawnictwo UNUM, Kraków 2003, 5 (2006), s. 314-316.

5. Lipiec D., Pastoralna posługa dziekana, 7 (2008), s. 248-259.

6. Rec. Swędrowski J.: Red. Urbański S., Śmigiera J., Gorzkie żale przybywajcie..., Wydawnictwo UKSW, Warszawa 2008, 7 (2008), s. 335-338.

7. Rec. Dziuba A. F.: Parzyszek Cz., Życie konsekrowane w posoborowym nauczaniu Kościoła, Wydawnictwo Księży Pallotynów „Apostolicum”, Ząbki 2007, 8 (2009), s. 199-203.

8. Rec. Skreczko A.: Osewska E., Edukacja religijna w szkole katolickiej w Anglii $i$ Walii w świetle Living and Sharing Our Faith. A National Project of Catechesis and Religious Education, Wydawnictwo Biblos, Tarnów 2008, 8 (2009), s. 207-209.

9. Skreczko A., Zrzeszenia eklezjalne jako pomoc w życiu wiara, 10 (2011), s. 131-143.

10. Rec. Swędrowski J.: Niestępski J., Twórczość homiletyczna biskupa Mikołaja Sasinowskiego w latach 1970-1982 oraz jej aspekty pastoralne, Drukarnia Archidiecezjalna w Katowicach, Warszawa 2009, 10 (2011), s. 269-270.

11. Rec. Swędrowski J.: Siwek G., Rekolekcje wczoraj i dziś, Wydawnictwo Homo Dei, Kraków 2011, 10 (2011), s. 271-275.

12. Rec. Osewska E.: Red. Stala J., Dzisiejszy bierzmowany. Problemy i wyzwania, Jedność, Kielce 2005, 10 (2011), s. 260-262.

\section{Teologia ascetyczna}

\section{A) Zagadnienia ogólne}

1. Martyniuk Paisjusz, Duchowość Wschodu, 1 (2002), s. 53-63.

2. Urbański S., Duchowość Kościoła Zachodniego, 1 (2002), s. 65-77.

3. Olech J., Życie zakonne w Europie wobec zachodzacych zmian politycznych, 3 (2004), s. 51-66.

4. Pałubska Z., Chrześsijańskie doświadczenie mistyczne, 3 (2004), s. 67-76.

5. Kimsza R., I wszystko co stworzył Bóg było piękne..., 3 (2004), s. 105-111.

6. Pałuska Z., Modlitwa prośby z kazaniach i mowach religijnych Arcybiskupa Józefa Teofila Teodorowicza, 7 (2008), s. 194-221.

7. Rec. Dziuba A. F.: Płatek J. S., Wybrane zagadnienia z historii i duchowości paulinów, Paulinianum, Wydawnictwo Zakonu Paulinów, Jasna Góra - Częstochowa 2009, 8 (2009), s. 195-198. 
8. Rec. Kimsza R.: Marciano S., Pellicanò P., «... Secondo il mio cuore...» (Ger 3, 15) Sessualità, affettività e vocazione allamore: un itinerario formativo, un cammino spirituale, San Paolo Edizioni 2001, 10 (2011), s. 266-268.

\section{B) Wzory życia}

1. Nitkiewicz K., Duchowość chrześcijańska w rozumieniu Stugi Bożego ks. Michała Sopoćki, 1 (2002), s. 79-88.

2. Ciereszko H., Eucharystia w życiu i posłudze kapłańskiej księdza Michała Sopoćki, 4 (2005), s. 47-57.

3. Perzyński A., Życie duchowościa dziecięctwa według Anzelma Gądka OCD (1884-1969), 6 (2007), s. 84-95.

4. Urbański S., Duchowość miłosierdzia według bł. Michała Sopoćki, 7 (2008), s. 13-30.

5. Zabielski J., Roztropność i męstwo Błogosławionego ks. Michała Sopoćko w rozwoju kultu Bożego Miłosierdzia, 7 (2008), s. 31-46.

6. Hardyś J., Ofiarniczy charakter życia duchowego Świętej Teresy z Los Andes oraz Błogosławionych Hiacynty i Franciszka Marto, 7 (2008), s. 165-178.

7. Puchalska-Dąbrowska B. M., Święta Elżbieta Wegierska - wzorzec stanowy dla kobiet w hagiografii polskiej XVI-XVIII wieku, 7 (2008), s. 179-193.

8. Machniak J., Boże Miłosierdzie w doświadczeniu św. Faustyny Kowalskiej i w teologii bł. ks. Michała Sopoćki - dynamika przyjaźni duchowej, 8 (2009), s. 85-97.

9. Puchalska-Dąbrowska B. M., Aktualność św. Elżbiety Wegierskiej jako małżonki i matki w świetle materiałów formacyjnych Franciszkańskiego Zakonu Świeckich 2007-2008, 8 (2009), s. 167-174.

10. Buzun Ł., Chrystocentryzm życia duchowego w nauczaniu św. Józefa Sebastiana Pelczara, 9 (2010), s. 79-93.

11. Puchalska-Dąbrowska B., Egzempla z życia świętych w „Dyrektorium” bł. Bolesławy Lament, 10 (2011), s. 171-186.

\section{C) Asceza kapłańska}

1. Dziuba A. F., Starsi kapłani we wspólnocie kościoła diecezjalnego, 8 (2009), s. $42-58$.

\section{D) Inne}

1. Pałubska Z., Macierzyństwo duchowe w Kościele katolickim, 6 (2007), s. 96-117.

2. Rec. Dziuba A. F.: Michalak U., Sens bycia człowiekiem. W poszukiwaniu ostatecznej perspektywy życia osobowego, Archidiecezjalne Wydawnictwo Łódzkie, Łódź 2006, 7 (2008), s. 324-326.

3. Rec. Puchalska-Dąbrowska B. M.: Sokołowska K., Świeckich droga do świętości w hagiografii sarmacko-barokowej, Wydział Teologiczny UAM, Poznań 2008, 9 (2010), s. 268-270. 


\section{Historia Kościoła}

\section{A) Kościoły i parafie}

1. Kasabuła T., Początki Kościoła katolickiego łacińskiego na Białorusi, 2 (2003), s. 89-103.

2. Krahel T., „Kronika” kościoła farnego w Grodnie, 2 (2003), s. 117-123.

3. Rec. Kasabuła T.: Lietevos istorijos šaltiniai, t.VI, Vyskupo Ignoto Jokûbo Masalskio kauno dekanato vizitacija $1782 \mathrm{~m}$., oprac. Vytautas Jogèla, Katalikų Akademija, Vilnius 2001, 2 (2003), s. 155-161.

4. Szot. A., Przejęcie przez władze państwowe ksiąg metrycznych w 1949 r. (w polskiej części archidiecezji wileńskiej), 3 (2004), s. 113-131.

5. Krahel T., „Kronika” kościoła parafialnego w Różanymstoku, 3 (2004), s. 145-151.

6. Rec. Krahel T.: Fil G.S., Rimsko-katoliczekij prichod sw. Iosifa w Tjumenti (minuwszeje i nastojaszczeje), Izdatielstwo „Wektor Buk”, Tjumeń 2004, 3 (2004), s. $182-183$.

7. Kakareko A., Kościoły parafialne $w$ Wilnie $w$ świetle relacji o stanie diecezji i statutów synodów wileńskich (XVI-XVIII w.), 4 (2005), s. 99-110.

8. Kasabuła T., Kanonicy koadiutorzy w kapitule katedralnej wileńskiej w okresie przedrozbiorowym, 4 (2005), s. 111-127.

9. Krahel T., Materiały do dziejów budowy katedry w Białymstoku, 4 (2005), s. 225-236.

10. Stala J., Implikacje historyczno-społeczne działalności duszpasterskiej i katechetycznej Kościoła $w$ Polsce i Kościoła tarnowskiego w pierwszych latach po II wojnie światowej, 5 (2006), s. 199-209.

11. Rec. Kasabuła T.: Bendza M., Szymaniuk A., Starożytne patriarchaty prawosławne, Wydawnictwo Uniwersytetu w Białymstoku, Białystok 2005, 5 (2006), s. 303-308.

12. Krahel T., Od wileńskiej do białostockiej archidiecezji i metropolii, 6 (2007), s. 149-157.

13. Kasabula T., Rozwój sieci kościołów parafialnych, rektoralnych i pomocniczych $w$ archidiecezji w Białymstoku w latach 1945-1989, 6 (2007), s. 158-176.

14. Szot A., Kronika parafii Majewo autorstwa księdza Mieczysława Skrobota, 6 (2007), s. 179-192.

15. Kasabuła T., Poczatki organizacji terytorialnej Kościoła katolickiego obrządku łacińskiego $w$ Cesarstwie Rosyjskim (w 225. rocznice powstania archidiecezji i metropolii mohylewskiej), 7 (2008), s. 260-271.

16. Sopoćko M., Życie religijne w Metropolii Wileńskiej 1939-1945 (przygotował do druku ks. Tadeusz Krahel), 7 (2008), s. 293-308.

17. Rec. Kasabuła T.: Oprac. Firkovičius R., Lietuvos istorijos šaltiniai, t. VII, Breslaujos dekanato vizitacija $1782-1783 \mathrm{~m}$. altikta vilniaus vyskupo Ignoto 
Jokūbo Masalskio parèdymo, Lietuvių Katalikų Mokslo Akademija, Vilnius 2008, ss. 452+XI (Źródła do dziejów Litwy, t. VII, Wizytacja dekanatu brasławskiego 1782-1783 r. przeprowadzana na polecenie biskupa wileńskiego Ignacego Jakuba Massalskiego), Litewska Katolicka Akademia Nauk, Wilno 2008, 9 (2010), s. 271-275.

18. Rec. Kalisz Ł.: Walewander E., Pedagogia katolicka $w$ diecezji lubelskiej 19181939, TN KUL, Lublin 2007, 9 (2010), s. 279-281.

\section{B) Biografie i wspomnienia pośmiertne i inne personalia}

1. Kasabuła T. , Prymas kardynat Wyszyński w archidiecezji w Białymstoku, 1 (2002), s. 7-19.

2. Kakareko A., List pasterski biskupa wileńskiego Jerzego Radziwiłła $z$ dnia 25 lutego 1582 r., 2 (2003), s. 107-115.

3. Pałubska Z., Duchowe przesłanie arcybiskupa Jozefa Teofila Teodorowicza $w$ „Kazaniu sejmowym” $z 2$ II 1919 roku, 4 (2005), s. 129-144.

4. Szot A., Ks. dr Witold Kuźmicki - proboszcz i dziekan dąbrowski (w latach 1936-1943), 5 (2006), s. 247-271.

5. Rec. Pietrzykowski J.: Krahel T., Doświadczeni zniewoleniem. Duchowni archidiecezji wileńskiej represjonowani w latach okupacji sowieckiej (1939-1941), Polskie Towarzystwo Historyczne - Oddział w Białymstoku, Białystok 2005, 5 (2006), s. 299-302.

6. Rostkowski Z., Życie i działalność pasterska ks. bp. Franciszka Jaczewskiego (1832-1914), 8 (2009), s. 134-148.

\section{C) Inne zagadnienia historyczne}

1. Kakareko A., Synod Biskupa Aleksandra Kotowicza z 1685 r., 3 (2004), s. 135-143.

2. Rec. Kasabuła T.: Red. Ślusarska M., Dwór, plebania, rodzina chłopska. Szkice $z$ dziejów wsi polskiej XVII i XVIII wieku, DiG, Warszawa 1998, 3 (2004), s. $177-181$.

3. Szot A., Kongres Eucharystyczny w Archidiecezji Wileńskiej w 1931 r., 4 (2005), s. $145-163$.

4. Prokop R. K., Sukcesja apostolska biskupów i arcybiskupów wileńskich oraz białostockich w XIX i XX stuleciu, 4 (2005), s. 165-210.

5. Prokop K. R., Sakry i sukcesja święceń biskupich pasterzy Kościoła wileńskiego $z$ drugiej oraz trzeciej tercji XVIII stulecia, 5 (2006), s. 211-246.

6. Hoffmann J., Znaczenie rzymskich wspólnot chrześcijańskich $i$ ich biskupa dla całego Kościoła w pierwszych trzech wiekach chrześcijaństwa, 7 (2008), s. 272-290.

7. Rec. Dziuba A. F.: Panuś K., Historia kaznodziejstwa, Wydawnictwo Salwator, Kraków 2007, 7 (2008), s. 321-323. 
8. Szot A., Normalizacja, której nie było... Katechizacja na Białostocczyźnie w latach 1956-1961, 9 (2010), s. 208-230.

\section{Prawo kanoniczne}

1. Syczewski T., Kult świętych oraz obrazów świętych i relikwii w obowiązującym prawodawstwie Kościoła łacińskiego, 7 (2008), s. 144-152.

\section{Nauki biblijne}

1. Dziuba A. F., Dynamika miłosierdzia w orędziu nagrody i kary, 7 (2008), s. 71-97.

2. Kułaczkowski J., Skutki miłosierdzia okazywanego ojcu wobec syna w ujęciu Syr 3, 14-15, 7 (2008), s. 98-109.

3. Gądecki S., Teologia uczniostwa, 7 (2008), s. 120-134.

4. Murziński P., Koncepcja czasu u Koheleta, 7 (2008), s. 135-143.

5. Najda J., Święty Paweł a areopagi współczesności, 8 (2009), s. 98-111.

6. Zabielski J., Biblijna aksjologia życia społecznego chrześcijan, 10 (2011), s. 88-102.

7. Turowski W., Komunikacja Słowa Bożego a komunikat zwrotny, 10 (2011), s. $144-160$.

\section{Apologetyka i teologia fundamentalna}

1. Murziński P., Kościół w Polsce wobec sekt i nowych ruchów religijnych, 9 (2010), s. $154-169$.

\section{Filozofia}

1. Ozorowski E., Ontyczne podstawy personalizmu, 3 (2004), s. 9-18.

2. Ozorowski E., Personalizm chrześcijański, 4 (2005), s. 5-17.

3. Rec. Ozorowski E.: De Lubac H., Dramat humanizmu ateistycznego, Kraków 2004, 5 (2006), s. 281-285.

4. Ozorowski E., Nauka a pytania graniczne, 6 (2007), s. 7-10.

5. Murziński P., Światopogląd a wiara w Boga we wspótczesnym świecie, 10 (2011), s. 103-112.

6. Chorab M., Ujęcie zła w filozofii Paula Ricoeura, Jeana Naberta, Gabriela Marcela, 10 (2011), s. 221-231.

\section{Dział ogólny}

\section{A) Od redakcji, słowa wstępne}

1. Ozorowski E., Słowo wstępne, 7(2008), s. 9-13. 
2. Ozorowski E., Nauki potrzebuja teologii 8 (2009), s. 9.

3. Kasabuła T., X lat Międzywydziałowej Katedry Teologii Katolickiej, 8 (2009), s. 10-29.

4. Kasabuła T., „Rocznik Teologii Katolickiej” w pierwszym dziesięcioleciu swego istnienia, 10 (2011), s. 11-20.

5. Proniewski A., Bibliografia artykułów w „Biuletynach” $i$ „Rocznikach Międzywydziałowej Katedry Teologii Katolickiej w Białymstoku w pierwszym dziesiecioleciu swego istnienia", 10 (2011), s. 21-40.

\section{B) Sprawozdania z konferencji, sympozjów i działalności naukowej}

1. Kasabuła T., Sprawozdanie z sympozjum „Duchowość chrześcijańska Wschodu i Zachodu" (25-26 stycznia 2002 r.), 1 (2002), s. 89-96.

2. Kasabuła T., Katedra Teologii Katolickiej Uniwersytetu w Białymstoku - sprawozdanie z działalności za rok 2001, 1 (2002), s. 97-101.

3. Krahel T., Międzynarodowa konferencja naukowa „Vyskupas Anantas Baranauskas: asmenybe ir aplinka" (Biskup Antoni Baranowski: osobowość i środowisko) Wilno, 21-22 listopada 2002 roku, 2 (2003), s. 127-129.

4. Proniewski A., Sympozjum: „Uniwersytet i Kościół w Europie” Rzym, 18-20 lipca 2003 roku, 2 (2003), s. 130-133.

5. Skreczko A., IV Światowe Spotkanie Rodzin: „Rodzina chrześcijańska - dobra nowina na trzecie tysiąclecie" Manila (Filipiny), 22-26 stycznia 2003 roku, 2 (2003), s. 134-138.

6. Kasabuła T., Sprawozdanie z działalności Międzywydziałowej Katedry Teologii Katolickiej Uniwersytetu w Białymstoku (1 I 2002 - 30 IX 2003), 2 (2003), s. 139-145.

7. Skreczko A., Sprawozdanie z VII Kongresu Teologów Polskich w Katolickim Uniwersytecie Lubelskim, Lublin 12-15.09.2004, 3 (2004), s. 155-158.

8. Proniewski A., Sprawozdanie z Międzynarodowego Kongresu Naukowego „Karl Rahner i zagadnienie antropologii: problematyka i perspektywy”, Rzym 4-5 marca 2004, 3 (2004), s. 159-163.

9. Kasabuła T., Sprawozdanie z działalności Międzywydziałowej Katedry Teologii Katolickiej Uniwersytetu w Białymstoku w roku akademickim 2004/2005, 4 (2005), s. 239-245.

10. Kasabuła T., Sprawozdanie z działalności Międzywydziałowej Katedry Teologii Katolickiej Uniwersytetu w Białymstoku w roku akademickim 2005/2006, 5 (2006), s. 275-280.

11. Kasabuła T., Sprawozdanie z działalności Międzywydziałowej Katedry Teologii Katolickiej Uniwersytetu w Białymstoku w roku akademickim 2006/2007, 6 (2007), s. 195-203. 
12. Proniewski A., Trzecie Międzynarodowe Sympozjum Naukowe pt. „Politica senza religione? Laicità dello stato, appartenenze religiose e ordinamento giuridico", 9-11.09.2007 Lugano (Szwajcaria), 6 (2007), s. 204-207.

13. Szot A., Sprawozdanie z konferencji naukowej pt. „Exodus - deportacje i migracje (wątek wschodni). Stan i perspektywy badań", 6 (2007), s. 208-212.

14. Kasabuła T., Sprawozdanie z działalności Międzywydziałowej Katedry Teologii Katolickiej Uniwersytetu w Białymstoku w roku akademickim 2007/2008, 7 (2008), s. 309-314.

15. Olszewski M., Sprawozdanie z sympozjum PosT Netzwerk 18-21 IX 2008 Celje (Słowenia), 7 (2008), s. 315-318.

16. Szot A., Sprawozdanie z międzynarodowego sympozjum naukowego zorganizowanego w Łomży dnia 23 października 2008 r. „190 rocznica powstania diecezji sejneńskiej”, 7 (2008), s. 319-320.

17. Kasabuła T., Sprawozdanie z działalności Międzywydziałowej Katedry Teologii Katolickiej Uniwersytetu w Białymstoku w roku akademickim 2008/2009, 9 (2010), s. 233-239.

18. Dzięgielewska A., Sprawozdanie z konferencji „Współczesne zagrożenia wiary od zewnątrz", 9 (2010), s. 240-242.

19. Osewska E., Sprawozdanie z Międzynarodowej Konferencji Naukowej „Nauczanie religii i katecheza w Europie ze szczególnym uwzględnieniem Polski, Anglii i Słowenii” („Religious Education and Catechesis in Europe with the Special Focus on Poland, England and Slovenia"), Słowenia, Ljubljana, 25 III 2010, 9 (2010), s. 243-245.

20. Kasabuła T., Sprawozdanie z działalności Międzywydziałowej Katedry Teologii Katolickiej Uniwersytetu w Białymstoku w roku akademickim 2009/2010, 10 (2011), s. 235-237.

21. Kasabuła T., Sprawozdanie z działalności Międzywydziałowej Katedry Teologii Katolickiej Uniwersytetu w Białymstoku w roku akademickim 2010/2011, 10 (2011), s. 238-246.

22. Dzięgielewska A., Sprawozdanie z warsztatów duszpasterskich (Białystok, 01-02.03.2011 r.), 10 (2011), s. 247-249.

\section{C) Inne}

1. Jurkowski H., Teatr wobec sacrum - zarys problematyki, 3 (2004), s. 77-94.

2. Kasabuła T., Sprawozdanie z obchodów 50. Rocznicy śmierci arcybiskupa Romualda Jałbrzykowskiego „Między Wilnem a Białymstokiem” 14-15 czerwca 2005, 4 (2005), s. 246-251.

3. Rec. Ozorowski E.: Poupard P., W serce Watykanu. Od Jana XXIII do Jana Pawła II. Rozmowa z Marie-Joelle Guillaume, Katowice 2005, 4 (2005), s. 252-254.

4. Rec. Dziuba A. F.: The Polish Cultural and Scientific Heritage at the dawn of Third Millennium, red. E. Szczepanik, London 2003, 5 (2006), s. 294-298. 
5. Rec. Skreczko A.: Dziuba A. F., Chrześcijaństwo a kultura, Wydawnictwo Uniwersytetu Kardynała Stefana Wyszyńskiego, Warszawa 2008, 8 (2009), s. 207-209.

6. Rec. Rostkowski Z.: Leonelli A., Fermo posta. Paradiso, wyd. Tipo-Litografia Paltrineri, Modena 2007, 8 (2009), s. 212-216.

7. Wierzbicka B., O zwierzętach rodem $z$ „Biblii” w polskich XVI-wiecznych romansach rycerskich, 10 (2011), s. 187-200. 